\title{
Economic Aspects of the World Mineral Situation
}

\author{
By Alfred G. White*
}

Bureau of Mines, Washington, D. C.

THE results of the Peace Conference will largely determine
the future of nations. Each nation, whatever its present state of development, ultimately hopes to rise in the industrial scale from a producer and exporter of crude raw materials to the position of greater wealth and higher organization attained by a manufacturing nation. The control of natural resources is one of the important factors under consideration. Resources are very unevenly distributed and the control of one important world product is a diplomatic asset to the nation possessing it. Danger of too great dependence upon other countries has been emphasized by the war. Such dependence has involved the diversion from military service of the ship tonnage required for the actual import of the materials, for the return movement of fuel, equipment and supplies required in their production, and for the transportation of other less essential products insisted upon by the nations possessing them. In addition to the sacrifice of shipping and to the uncertainty of supply, the importation of bulky raw materials has overtaxed port facilities and has required increased financial credits in purchasing materials abroad. During the war, essential supplies of raw materials were cut off and many nations were forced to attempt to develop their home resources, even under unfavorable conditions. The continuation of this attempt may no longer be necessary if world security and peace can be permanently established and an equitable distribution of raw materials assured.

\section{The Importance of Minerals}

The war has greatly emphasized the importance of minerals, which rank with foods and textiles among the great and essential groups of raw materials. The fuels, iron and steel, copper, lead,

* Published with the permission of the Director of the U. S. Bureau of Mines. 
and zinc were fundamental materials. In addition there is a smaller group of "War Minerals" whose importance is far greater than either their tonnage or value would indicate. The two fundamental materials for the production of all modern high-power explosives are nitrate used chiefly in the form of nitric acid, and concentrated sulphuric acid made from pyrite or sulphur. Manganese is the most essential alloy for high-grade steel for munitions and important industrial uses. Tungsten and molybdenum are essential alloys for tool steel. Flake graphite is used for crucibles required in the production of brass and crucible steel. Tin is required for tin-plate for utensils and cans for preserving food and for bearing metal. Quicksilver is used as fulminate to explode cartridges and shells, and is essential for the safe and effective use of high-explosives. Potash is used chiefly for fertilizer. Antimony is required for hardening lead for bullets. Chromite is used to make an alloy for tool steel, for tanning leather, and as a refractory lining in basic open hearth steel furnaces. Magnesite is used as a refractory in metallurgical furnaces. Mica is indispensable as an insulating material in the manufacture of electrical apparatus. Platinum is important as a "contact" material in the manufacture of sulphuric acid for explosives.

The annual production of the more important minerals approximated about $1,800,000,000$ short tons prior to the outbreak of the European war. This does not include a number of minerals of more or less local significance, such as stone, cement, sand, and gravel. The relative weight of the various minerals produced in 1913, reduced to short tons, is as follows:

\begin{tabular}{|c|c|}
\hline Coal. & $1,480,000,000$ \\
\hline Iron Ore. & $195,000,000$ \\
\hline Oil. . & $55,000,000$ \\
\hline Salt. & $24,000,000$ \\
\hline Potash Salts. . & $13,000,000$ \\
\hline Phosphate Rock. & $7,000,000$ \\
\hline Pyrite. & $6,600,000$ \\
\hline Oil Shale. . & $4,000,000$ \\
\hline Nitrate. & $3,100,000$ \\
\hline Manganese Ore. & $2,600,000$ \\
\hline Lead. & $1,300,000$ \\
\hline Copper & $1,100,000$ \\
\hline
\end{tabular}


Zinc $1,100,000$

Sulphur 800,000

Bauxite 600,000

Crude Magnesite 600,000

Chromite.............. $\quad \mathbf{2 0 0 , 0 0 0}$

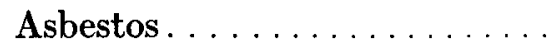
180,000

Tin. 140,000

Graphite............... 140,000

Nickel. . . . . . . . . . . . . . 32,000

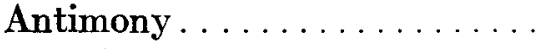

Arsenic. 27,000

Silver. 16,000

Tungsten .

9,320

Quicksilver

9,000

Sheet-Mica 4,400

Vanadium. 4,000

Gold

Molybdenum..............

244

Platinum . . . . . . . . . . . . .

These figures of relative bulk must be kept in mind as the further discussion will deal with percentages of output. While one per cent of the world's coal output represents approximately $15,000,000$ tons, one per cent of the world's production of platinum is only a small fraction of a ton.

For purposes of general discussion minerals may be grouped under three heads: fuels, metals, and non-metallic minerals.

\section{Fuels}

The principal minerals in this group are coal, petroleum (including shale oil), and natural gas. Considerable amounts of peat are used as fuel, but under present conditions it is of local significance.

Coal represents by far the largest tonnage in the mineral group. It may be divided into three sub-groups, anthracite, bituminous, and lignite. The anthracite is of principal significance as a smokeless domestic fuel. Bituminous is further divided into two significant groups, coking and non-coking. Coking coal is required in the principal metallurgical operations and is important in the 
development of smelting industries. Non-coking bituminous coal is used for power and industrial purposes, for railroad and bunker purposes, and in the absence of anthracite for domestic purposes. It represents the principal coal used for export purposes. Lignite coals are of lower grade and are generally restricted to local consumption.

Europe and North America are the principal coal producing continents. The 1913 production was as follows: United States, 39 per cent; Great Britain, 32 per cent; Germany, 21 per cent; Austria, 4 per cent; France, 3 per cent; Russia, 2 per cent; Belgium, 2 per cent; Japan, 2 per cent; India, 1 per cent; China, 1 per cent; Australia, 1 per cent; Canada, 1 per cent; and all others 1 per cent. Great Britain, Germany, and the United States were the principal exporting nations, with a smaller amount from Japan and Australia. Practically all the other important producers used their production for home consumption and required additional imports. Most of the principal producers are capable of continuing production for a considerable period of time. The great future reserves of the world are held by the United States with one-half of the total, Canada with one-sixth, and China with one-seventh. Great Britain's reserves are smaller, but of the highest average quality. A considerable part of the world's reserves consist of the lower grade lignite coals. The net effect of the war on the coal industry was to cut off the German export, to cause a decline of over 20 per cent in the British export, and to considerably increase the export from the United States to both Europe and South America.

Soon after the beginning of the war, Germany increased her control over coal resources by the capture of fields producing about one-half the French output, by the capture of all of the Belgian coal fields, and by the capture of the coal field in Poland producing about one-fifth the total Russian supply. This increased the German and Austrian control of this important fuel by about 4 per cent. On the whole the production of coal has been less than normal since the war began. In most countries production has declined from 10 to 20 per cent except in the United States where it has increased to meet the demands incident to the manufacture of munitions and to a greater export trade. 


\section{Petroleum and Petroleum Products}

Petroleum may be used in its crude state as fuel oil for industrial, railroad, and steamship purposes, or it may be refined into a number of products of wide significance. The principal ones are gasoline for internal combustion engines, kerosene used largely for lighting purposes, lubricating oils, residuum used as fuel oil, and asphaltum for road making. Improvements in refining and cracking processes are resulting in the recovery of a larger percentage of the high-grade products and a corresponding decrease in the amount of oil used for heavy fuel purposes. A minor but significant source of supply for oil products is the distillation of shales which has been principally developed in Scotland, but large reserves are available in the United States.

The use of petroleum and petroleum products was greatly expanded during the war. Large amounts of fuel oil were required for allied naval operations, and the demand for gasoline and motor spirit was enormously increased by the use of motor trucks, aeroplanes, submarines, and tanks.

North America and Europe are the principal petroleum producing continents. The relative importance of 1913 world production was: the United States, 64 per cent; Russia, 17 per cent; Mexico, 7 per cent; Roumania, 4 per cent; Dutch East Indies, 2 per cent; Austria, 2 per cent; India, 2 per cent, and all others 2 per cent. As far as reserves are concerned, the United States will hold its leading position for many years to come. Russia may ultimately be expected to be the leading world producer. Mexico has very extensive reserves and its production is rapidly increasing. Very large undeveloped areas of great promise are known in Persia. During the war the Russian production was available for Russia's requirements and the principal oil territory was occupied by the British after the collapse of Russia. Germany was greatly handicapped because of the small amount of petroleum available for her use. The Austrian output from Galicia was - available and the Roumanian fields were later captured, but these fields were partially destroyed and were only brought back to somewhere near normal production at the close of the war. Although Germany was able to use railroad facilities to a greater extent, relied less on motor trucks, and did not have the heavy 
demands for naval operations, the shortage was very keenly felt. The Allies relied largely on production from the United States and Mexico, the principal limit of supply being the shortage of tank steamers which was intensified by losses from submarine attacks. Both the United States and the Mexican production was very greatly increased and Mexico probably took second rank among the producers in 1917.

Natural gas is a very important fuel which has been principally produced in the United States. Because of the fact that it must be piped to the point of consumption, it is generally used in relatively local areas and does not enter into export or long distance transportation.

While hydro-electric power has been largely developed in many districts and comes into competition with the natural mineral fuels, it is again a matter of relatively local use and does not offer any immediate prospect of replacing the other principal fuels although it will occupy an increasing field.

\section{Metals}

The metal group may be divided into several sub-divisions, the largest of which is iron and steel including the steel alloys.

Iron ore takes second place among the bulky mineral products. The iron and steel industries which make use of it, have generally been located with respect to the coking coal supply, so that a nation which possesses iron and does not possess coal has not become important in steel manufacturing.

Europe and North America are the principal iron ore producing continents. The relative importance of the 1913 world production by countries was: the United States, 36 per cent; Germany, including Luxemburg, 20 per cent; France, 12 per cent; the United Kingdom, 9 per cent; Russia, 5 per cent; Spain, 5 per cent; Sweden, 4 per cent; Austria, 3 per cent; Canada, 1 per cent; Cuba, 1 per cent and all others 4 per cent. The present principal producing districts contain large reserves and no immediate shifting of the industry is probable. Brazil and China have vast reserves which have so far been little developed. Newfoundland also has large reserves which so far have been developed only on a small scale. The principal effect of the war on the iron ore situation was the seizure of a large part of the French producing districts by 
Germany early in the war. With the close of the war and the probable return of the Lorraine iron deposits to France, Germany will lose practically 70 per cent of her known iron deposits representing about 60 per cent of her pre-war production, thus increasing French control from 12 to 24 per cent and decreasing German control from 20 to 8 per cent of the normal world output.

The production of pig iron in the United States increased almost one-third while that of most countries declined. This indicates the extent to which the allied nations depended on this country for war materials.

Of the steel alloys, manganese and chrome represent the minerals involving the larger tonnages. Before the war Russia produced 56 per cent of the world's manganese, India 35 per cent, and Brazil 5 per cent. The export of Russian manganese was cut off by the closing of the water route via Constantinople. The shipments from India were largely curtailed by the shortage in ocean shipping. Under these circumstances Brazil was more favorably situated, and her output increased over four fold. Before the war Rhodesia furnished 35 per cent of the output of chromite, New Caledonia 35 per cent, Russia 13 per cent, and Asiatic Turkey 8 per cent. While the principal sources of New Caledonia and Rhodesia remained available, shipments were interrupted, because of the difficulties of ocean transportation, and the situation necessitated conservation in the use of this essential mineral. Production in the United States and Canada was greatly stimulated so that at the close of the war these countries were large producers. Because of the handicap of transportation and lower grade deposits, it is doubtful whether much of this output will be permanent. Tungsten, molybdenum, vanadium, and cobalt, while important as special alloys, are produced in very small tonnages. The pre-war production of tungsten came from Asia, 28 per cent; United States, 16 per cent; Australia and New Zealand, 15 per cent; Spain and Portugal, 14 per cent, and South America, 14 per cent. Practically all of these sources remained available as the total tonnage was relatively insignificant. Under the stimulus of high war prices the world production was doubled. The United States and Australia were the principal producers of molybdenum, with Norway as third in importance. Because of the small tonnage of this alloy and its restricted use, the situation 
was not greatly disturbed. Peru and the United States were the principal sources of vanadium, the former having the largest and most important deposits in the world. The production of vanadium varies considerably from year to year and the situation was not greatly disturbed. The principal supply of cobalt comes from Canada. The steel alloy group as a whole is a most significant one because of the production of special steels which are absolutely essential for such purposes as tool steel, automobile and machine parts, and munition manufacture.

\section{Non-Ferrous Metals}

The second sub-division of metals includes the principal nonferrous metals such as copper, lead, zinc, tin, aluminum, and nickel. The tonnage involved is relatively small compared to the great variety of manufactured products into which they enter.

North America produced two-thirds of the world's copper in 1913. The United States ranked first with 56 per cent, with Japan as second with only 7 per cent, and Mexico, Spain, and Australia each 5 per cent. The rest of the production is widely scattered. The Central Powers produced only about 3 per cent of the total, and were greatly handicapped by the lack of this essential metal. The United States will probably continue to be the principal producer for many years. Outside of the United States, Chile and the Kongo Independent State have the largest known reserves. The production of copper increased by 50 per cent during the war.

North America furnished 43 per cent of the world's output of lead, Europe 30 per cent, and Australia 20 per cent. The principal countries in their order of importance were: United States, 36 per cent; Australia, 20 per cent; Spain, 16 per cent; Germany and Austria, 8 per cent, and Mexico, 5 per cent. The United States production increased 40 per cent during the war while in other countries it declined. The leading zinc producing continents were Europe, 43 per cent; North America, 36 per cent, and Australia, 15 per cent. The principal countries were: the United States, 35 per cent; Germany, 25 per cent; Australia, 15 per cent; Italy, 5 per cent, and Algeria, 3 per cent. The rest of the production was widely scattered. The principal effect of the war was the disturbance of smelting facilities, a considerable part of which was 
located in Belgium and Germany. Much of the Australian concentrates had to be shipped temporarily to the United States for smelting. With regard to tin, Southern Asia and the East Indies produced 65 per cent, and Bolivia 20 per cent, with smaller amounts in Australia, England and Africa. The Central Powers have no production of this important mineral. While world transportation conditions were difficult, the tonnage was relatively small and no serious war shortage resulted although curtailment in non-essential uses was necessary. Bauxite, the ore from which aluminum is made, was produced almost entirely by two countries: France, 57 per cent, and the United States, 40 per cent. The output greatly increased due to war demands as aluminum was largely used in the construction of aeroplane and automobile parts. Canada has almost a world monopoly of nickel, producing 84 per cent, while New Caledonia produced about 11 per cent. In summarizing this important group of minerals we may observe that the Central Powers had almost no production of copper, aluminum, nickel, and tin, and were thus severely handicapped.

\section{The Precious Metals}

The third sub-division is the precious metal group, including gold, silver, and platinum. The tonnage of the finished products is insignificant compared with their financial and industrial importance. All three of these metals have been used largely for jewelry and other less essential purposes. Gold and silver are of essential importance principally from a financial standpoint, while platinum was of special war significance because of its use in the production of sulphuric acid by the contact process and for essential parts in electrical apparatus. In 1913 South Africa was the most important gold producing section with 44 per cent of the world output, the United States was second with 19 per cent, Australasia follows with 12 per cent, Russia with 6 per cent, Canada 4 per cent, Mexico 4 per cent. The rest of the production was widely scattered. In the production of silver, North America was the leading continent with $\mathbf{7 7}$ per cent distributed as follows: Mexico, 32 per cent; the United States, 30 per cent, and Canada, 14 per cent. Australia was next with 8 per cent, and then Peru with 4 per cent and Germany and Austria with 3 per cent. Russia produced 93 per cent of the world's platinum, and Colombia 
furnished most of the remainder. The Russian production declined during the war and was cut off after the collapse of Russia. The output of Colombia very largely increased, but the increased war demand for platinum resulted in a campaign to restrict its use for jewelry and less essential purposes. The production of both gold and silver declined to an alarming extent during the war. This was due to the increasing cost of labor and supplies for mining while the purchasing value of the product-the dollardeclined in proportion.

The fourth sub-division includes metals such as quicksilver, antimony, magnesium, radium, and a number of others of less importance. Quicksilver was of particular war importance because of its use as fulminate in connection with the detonation of high explosives. Four countries produced the larger part of the world supply before the war as follows: Spain, 31 per cent; Italy, 25 per cent; Austria, 22 per cent, and the United States, 14 per cent. The United States output largely increased during the war. China has been the principal source of antimony with a production of 53 per cent in 1913, with France second with 24 per cent, and the United States third with 8 per cent. The Chinese deposits are extensive and cheaply mined and production rapidly increased during the war. A considerable amouni of the metal magnesium was produced as a light alloy for aeroplane construction. Radium has been of prime importance because of its use in the treatment of cancer. Certain compounds of radium have been largely used in luminous parts for watches and various military equipment.

\section{Non-Metaluic Minerals}

The non-metallic minerals may also be sub-divided into several groups. The largest, from a standpoint of tonnage, is the building and structural group.

The minerals include stone, clay, sand, gravel, and asphalt. Secondary manufactured products are cement, brick, and pottery. These minerals are bulky and of wide distribution, therefore they are generally restricted to local markets, where they are used for building purposes, for road materials, and other structural work. Some of the higher grades of clay and stone serve special manufacturing or ornamental purposes and may be transported long distances, but these are exceptions to the general rule. 
A second sub-division is the fertilizer group. The three most important minerals are nitrate, potash, and phosphate. The principal deposits of these minerals are concentrated in a few places and they largely enter into world commerce. Chile produces practically all of the output of natural nitrate. The production of artificial nitrates by various electrical and chemical processes has been expanded and probably furnished a considerable part of the German supply which was supplemented by large stocks accumulated before the war. Chile furnished the larger part of the supply required by the Allies for the manufacture of explosives. The transportation of several million tons of this material was a serious problem and resulted in considerable curtailment of its use for fertilizer. Germany had a similar monopoly control with regard to potash, producing practically all of that essential fertilizer. The world's supply was cut off with the outbreak of the European war.

A considerable development from natural deposits and from byproduct sources took place in the United States so that at the end of the war a production capacity had been developed to meet onethird of the requirements. This development took place under the stimulus of very high prices and it remains to be seen how much of this industry can survive the handicap of high freight rates from the western deposits which have furnished a large part of the output.

The supply of phosphate rock comes principally from the United States, 45 per cent, and from Northern Africa, 35 per cent. France was third with only 5 per cent, with smaller amounts from Belgium, and several small islands of the Pacific. A shortage of labor and ocean shipping, together with the loss of the German market, largely decreased the total production of this material.

A third sub-division is the chemical and metallurgical group. Pyrite and sulphur are used in the manufacture of sulphuric acid, in the production of sulphite wood pulp, and for a great variety of other chemical purposes. The largest production of pyrite comes from a district in Spain, a small part of which extends into Portugal. This district furnished 61 per cent of the world's output before the war. Norway was second in importance with 8 per cent, and the rest of the production was widely scattered. A considerable increase in the United States and Canadian produc- 
tion took place, but the principal war demands were met by an enormous expansion in the production of sulphur. Italy ( 47 per cent) and the United States (44 per cent) produced the great bulk of the world's sulphur output with the remainder of about 8 per cent coming from Japan. The production in the United States has been very rapidly increased and was almost on a par with that of Italy before the war. During the war the United States production expanded almost four fold, giving it preëminence as a world producer while the production of Italy suffered a serious decline.

Graphite and magnesite are largely used for refractory purposes in the metallurgical industry. The flake graphite is used for crucibles for melting brass and steel. Ceylon, Austria and Madagascar were the principal sources of supply before the war. The production of Madagascar was very largely increased. A large increase in the United States industry took place. Austria produced three quarters of the world output of magnesite, and when this supply was cut off at the beginning of the war, it created a problem in the steel industry where it was largely used as a refractory furnace lining. A great expansion took place in the United States industry in California and Washington, which met our requirements, while the Grecian output also was expanded so that no serious suffering resulted from the war situation. Salt is a mineral of large tonnage, very widely used for many purposes; fuller's earth, borax, barites, and arsenic are other numbers of this group.

Another sub-division includes miscellaneous minerals, such as asbestos, mica, abrasives, and others of less importance. Canada produced about 90 per cent of the world's supply of asbestos, with Russia as the country second in importance. The Canadian production has increased during the war while that of Russia has steadily declined. India produced about 60 per cent of the world's supply of sheet-mica, the larger part of the remainder coming from the United States and Canada.

\section{War Effects Summarized}

In summarizing the effect of the war on the world mineral situation there are three subjects to be discussed: (1) the changes in the national control of minerals during the war, (2) the development 
of new sources of supply of either a temporary or permanent character, and (3) the change in ownership of important resources which will probably result from the Peace Conference.

\section{Control of Minerals During the War}

The immediate effect of the war was a general disturbance and paralysis resulting from the closing of markets, the interruption of transportation routes for export, and a shortage of labor when the men were called to military service. A number of mineral districts of world importance were in the fighting zone and were partially destroyed, or for the time being rendered useless. The German occupation of Belgium and of large areas in France cut off an important part of the world's zinc smelting facilities, deprived France of about one-half of her normal coal supply, and cut off a large part of her iron and steel output. The loss of a large part of the market for American copper and phosphate rock which had been shipped to Germany seriously affected those industries. The exports of German coal and potash and of Austrian magnesite were stopped. With the entrance of 'Turkey into the war, Russian manganese ore could no longer find an outlet via Constantinople. Outside of these materials the rest of the world's mineral resources were available for the use of the Allies, but as the destruction of shipping increased, it became more and more difficult to secure a supply of the more bulky materials which had to be shipped long distances, such as coal from Europe to South America, pyrite from Spain to the United States, nitrate from Chile, manganese from India, and chromite from New Caledonia and Rhodesia.

The supply of minerals available for use by the Central Powers came principally from Germany and to a lesser extent from Austria and Turkey. Very little material was secured from the nearby neutral countries of Norway, Sweden, The Netherlands, and Switzerland, as they have few important mineral resources, although some iron ore, pyrite and copper were imported from Norway and Sweden.

Germany and Austria produced 25 per cent of the world's pre-war coal output. This supply was largely increased by the occupation of the Belgian fields, the capture of fields producing about one-half of the French, output, and by the capture of the Dombrowa Basin in Poland producing about one-fifth of the total 
Russian supply. With the collapse of Russia the latter control was extended over one-half the Russian output. Production from these various captured fields declined very considerably, due to their partial destruction, but undoubtedly added from $\mathbf{4 0}$ to 50 million tons per year to the German control of coal supplies. Germany and Austria produced 23 per cent of the world's output of iron ore which was available for war purposes. In addition a considerable part of the French ore deposits, forming an extension of the German Lorraine field, was occupied early in the war. The available supply of the world output of other major metals was lead, 8 per cent; zinc, 26 per cent, and copper, 3 per cent. The lack of copper was very keenly felt. The Central Powers produced very little of the important steel alloy minerals; namely, 1 per cent of nickel, 2 per cent tungsten, 7 per cent molybdenum, and 8 per cent of chromite from Asiatic Turkey. When her accumulated supplies of these materials were exhausted, the quality of her steel products greatly deteriorated and was a very serious handicap in producing war equipment. The lack of any natural nitrate deposits was made up by the artificial production of nitrate which was greatly increased during the war.

The supply of petroleum was very inadequate, particularly in a war where motor vehicles played such an important part. Austria produced about 2 per cent of the world's oil output, and the occupation of Roumania added about 4 per cent additional to this supply, although a considerable part of this latter amount was not available due to the destruction of the oil fields before they were seized by the Germans.

Germany was poorly supplied with raw materials for sulphuric acid, controlling only about 5 per cent of the world's pyrite output and practically no sulphur. She had a practical monopoly on the entire world's supply of potash, but had inadequate supplies of phosphate rock and nitrate, and as a result the food supply was considerably affected.

Australia and Turkey were producing about 25 per cent of the quicksilver supply so that an adequate amount was available for war demands.

In summing up the mineral situation of the enemy countries we may conclude that they had fairly adequate supplies of coal and iron, zinc, lead, potash, magnesite, and quicksilver, but were 
seriously handicapped by a shortage in petroleum, copper, tin, aluminum, manganese, nickel, pyrite, sulphur, and nitrate. The shortage of these minerals and their resulting effect in the production of war munitions and food, was an important factor in the economic collapse of Germany.

\section{New Sources of Mineral Supply}

It is difficult to forecast how permanent may be the new sources of mineral supply. The increased production of artificial nitrates will undoubtedly compete with the monopoly of the natural supply of this mineral which Chile has long enjoyed. The discovery of natural deposits of potash in Spain and the United States and the development of many by-product sources may establish new permanent competing sources. The production of platinum from Colombia has been greatly increased. The further development of the tin deposits in Bolivia and the establishment of tin smelters in the United States to handle this ore is another development of importance. The tremendous increase in the output of manganese from Brazil will undoubtedly give that country a more important position in the trade than it has held in the past. The increased production of flake graphite from Madagascar has brought that island into the foremost rank of producers of this material. The tremendous increase of the output of sulphur in the United States will strengthen the position which that material had already secured in the world's market. With the development of new smelting facilities in other countries, it is probable that Germany cannot regain her position in the zinc industry. The United States demonstrated her ability to produce many essential minerals to meet war demands, such as manganese, chromite, pyrite, magnesite, and graphite. To what extent these new industries can permanently survive is not yet apparent.

\section{Changes Effected by the Peace Conference}

Certain important facts about the ownership of mineral deposits seem fairly well determined, of which the most important is the transfer of Alsace-Lorraine to France. By this change Germany will lose three-fifths of her iron ore production, representing, in 1913,12 per cent of the world's output. The transfer of the Alsace potash deposits will break the German monopoly of this essential 
mineral. While in 1913 these deposits produced only 5 per cent of the output, and the Stassfurt deposits produced 95 per cent, the deposits are large and capable of extensive development under French control. In addition a small and important percentage of mica output from German East Africa, and of phosphate output from the Pacific Islands will probably be transferred to the control of other nations. The latest negotiations have dealt with the coal deposits of the Saar Valley, which is located in the part of Germany bordering Lorraine. If the coal output from this district is put under the control of France, it will be an important factor in supplying the fuel for the iron and steel industry which is based on the Lorraine iron ore deposits above mentioned. 